\title{
Alpinia zerumbet an essential medicinal herb
}

\begin{abstract}
Herb is very crucial valued for its medicinal, aromatic or slavery qualities that contains a variety of chemical substances that act upon the body to prevent relieve, and treat illness. The herbal medicine has a long and respected history. The Alpinia zerumbet Roxb. are used as analgesic, anthelmintic, blood purifier, carminative , demulcent , diaphoretic , diuretic, expectorant, febrifuge, purgative, sedative, anti-inflammatory, cardiovascular etc a number of other ailments. In Brazil, A. zerumbet is one of the most cited plants for folk medicine and it has been suggested for use by Brazil's public health system (SUS). The current work focuses the properties of these plants and open gate for the further exploration in future of these plants due to a number of good medicinal values for human welfare.
\end{abstract}

Keywords: anti inflammatory; fever, folk medicine, traditional medicine
Volume 4 Issue 5 - 2018

\author{
Akhilesh Kumar,' Vimala Bind ${ }^{2}$ \\ IToxicology Division, CIB \& RC, India \\ ${ }^{2}$ Depatment of Zoology, KN Govt PG College Gyanpur, India
}

Correspondence: Akhilesh Kumar, Consultant (Toxicology), Toxicology Division, CIB \& RC, Faridabad, Haryana, India-I 2 I00I, India, Tel +9195 65490599 Email akhicibrc@gmail.com

Received: August 0I, 2018 | Published: September II, 2018

\section{Introduction}

A. zerumbet is herb inhabitant to north-eastern Asian country, Union of Burma (Myanmar), region of Indo-China, China and Japan, but it's been efficiently cultivated as an ornamental in whole region of South Asian countries and initiated to tropical and subtropic regions round the world as a medicative and food crop. ${ }^{1,2}$ In the Cuba it is known as a noxious weed. ${ }^{3}$ In other country like South Africa consider as invasive weed by the "The Global Invasive Species Programme". Herbs have a variety of uses inducing culinary, medicinal, and in some cases spiritual usage differs between culinary herbs and medicinal herbs. Herbs are an integral part of human life. Before we learned to hunt animals primitive man had depended on plants for both food and medicine. Medicines from plants were used to cure but simultaneously magic spells were intoned as the plant material was applied. There was the usual method of healing in most part of the world. The original name of Alpinia zerumbet was Zerumbet speciosum given by the J.C. Wendland in year of 1798. The species of genus Alpinia has inhibited throughout the south and Southeast Asian geographical region, up to Japan from Asian nation like India, southward to Papua, the Solomon Islands, Australia, Fiji, and Samoa countries. The herb of those plants like several different genus Alpinia, A. zerumbet is also cultivated by the human as a decorative in several different tropicaland semitropical countries. It conjointly commercially made within the US and Europe and earn money. A case of Alpinia nutans which one has been introduced to European nation before 1793. ${ }^{5}$

The herb Alpinia zerumbet is a most abundant, clustering evergreen herb which one form intense copse in classically wet situation of weather like rivulet banks and shady slopes, and they also found in naturally places like forests, riparian zones, and the areas of wetlands which one habiting stumpy altitudes places. ${ }^{6}$ In the South Africa country, Alpinia sp. ocur as a invading "waterway, outer region of forest, roadsides and the open space of urban included in moist places, warm places, coastal areas and at the inland regions". The Alpinia sp. is mostlty adopted the environment of the Cook Islands, which one habitat in the lowlands area and some areas of inland valleys. ${ }^{6}$ In the same way in Taiwan, Alpinia sp was greatly found at low altitudes of the whole island and also found at the adjacent islets. ${ }^{7}$

\section{Botanical classification}

Kingdom: Planteae-Plants

Sub-kingdom: Tracheobionta-Vascular plants

Super-division: Spermatophyta-Seed plants

Division: Magnoliophyta

Class: Lilliopsida-Monocotelydons

Sub-class: Zingiberadeaee

Order: Zingiberales

Family: Zingiberaceae-Ginger family

Genus: Alpinia Roxb-Alpinia $(P)$

Species: Alpinia zerumbet (Pers) B.L.Burtt \& R.M.Sm-shell plant (P)

Vernacular names of Alpinia zerumbet-Sanskrit-Vanardraka, Stulagrandhi; English-Jungle Ginger; Hindi- Banda , Narkachur, Chatiun; Malayalam-Mailanchi; Bengali-Punnag Champa; ManipuriKanghoo.

\section{Current status used as medicine in various ailments and future prospects}

The rhizome of Alpinia sp. medicinally taken as a stomachic, for indigestion, stomach-ache and diarrhoea, and it also used as an emetic, as an expectorant. They are externally applied for rheumatism, wounds, sores and ringworm and showed useful against them. Their leaves are used for the latter purpose as well, it also with the intention of drawing blood to the skin for better effects. This plant has only recently caught the attention of the academic medical community for its potent antioxidant and hypotensive properties. The Alpinia sp. have certain names known as light galanga, pink porcelain lily, shell flower, shell ginger, variegated ginger, butterfly ginger, yàn shanjiang in Chinese, get to in Japanese, and Sannin in the local dialect of Okinawa. Their leaves and the extracted oils of the Alpinia plant have long been used in Asia to relieve fevers and malaria, as well 
as to serve as a general health tonic. In the Okinawa, Japan, some population of their frequently cited as 'the healthiest on earth,' boasts an extraordinarily low incidence of cardiovascular disease, stroke and cancer, reported. Where, the leaves of Alpinia Zerumbet are widely consumed regularly, they consume it used to wrap rice dumplings and decocted into teas as normally. Like traditional medicines, it used as a part of their culture. Now, modern research has confirmed hypotensive and antioxidant activity in the leaves and rhizomes and extracts of the plant. It all comes together to show its potential benefits for diabetics, patients with atherosclerosis, and a wide range of skin diseases. Alpinia sp. flowers and rhizomes are good natural resources for their use of essential oils and also as spice crops. ${ }^{8}$ In the China it won't to treat ailments like abdomen disorders, puking and indigestion. Its rootstalk is historically applied as a viscus, carminative, astringent, tonic and sedative. However, the seed is employed to clear cold, invigorate the spleen and heat the stomach". Used of tea in Japan and Brazil that is formed of from the leaves is usually used as a hypertensive and water pill medication. ${ }^{9,10}$ A. zerumbet, is additionally cultivated as a plant life and flora for its engaging, typically varicolored leaves and hanging type inflorescences.

In 2007, Abdelnaser and its co-worker obtained essential oils from Alpinia zerumbet, and showed that they have enriched natural antioxidant in fresh leaves and rhizomes. De Araujo Pincho et al., ${ }^{11}$ revealed that the anti-nociceptive effects of essential oils of Alpinia zerumbet in male Swiss mice. The Antimicrobial activity of Alpinia sp. reported by various works time to times such as. ${ }^{12-15}$ Sunilson et al., ${ }^{16}$ studied antimicrobial activity of various extracts of Alpinia galanga were screened against the common food borne bacteria such as Escherichia coli, Salmonella enteriditis, Clostridium perfringens, Staphylococcus aureus, Campylobacter jejuni, Bacillus cereus and fungi such as Saccharomyces cerevisiae, Hansenula anomala, Mucor mucedo, Candida albicans using disc diffusion method. All the extracts showed significant antibacterial and antifungal properties.

Hemabarathy et al., ${ }^{17}$ reported the crude extract of Alpinia sp showed hepatoprotective in rats model. Ye Ying, ${ }^{18}$ revealed its has good properties against human immunodeficiency virus (HIV) type 1. Bendjeddou et al., ${ }^{19}$ reported its Immunostimulating activities in mice. Akhtar et al., ${ }^{20}$ Jaju Shivkanya et al., ${ }^{21}$ revealed that its antidiabetic and anti-inflammatory activities from the extract of rhizome of Alpinia sp. and state that these are a better hypoglycaemic agent. Qureshi $\mathrm{S}$ et al.,22 Dadang Riyanto ${ }^{23}$ also have reported it have antiulcer properties. The bioactive compounds isolated from alpinia were found to markedly promote hair cell growth. Kaempferol-3-O- $\beta$-dglucuronide (KOG) and labdadiene, two of the isolated compounds, increased the proliferation of human follicle dermal papilla cells by approximately $117 \%-180 \%$ and $132 \%-226 \%$, respectively, at 10 $100 \mu \mathrm{M}^{24}$

Recently published studies by de Souza et al., ${ }^{25}$ revealed that the essential oils and their major components showed the good effect against Rhodnius nasutus, a Vector of Chagas Disease. The essential oils of Alpinia species was obtained by hydrodistillation and analyzed by GC-MS having main constituent of A. zerumbet essential oil (OLALPZER) was terpinen-4-ol, which represented $19.7 \%$ of the total components identified. Another study Santos-Júnior et al., ${ }^{26}$ has showed that the effects of the essential oil of Alpinia zerumbet (Pers.) B.L. Burtt \& R.M. Sm. on healing and tissue repair after partial Achilles tenotomy in rats. They confirmed that the Oil of Alpinia zerumbet stimulated the process of maturation, organization and tissue repair which gave it greater resistance.

\section{Conclusion}

The widespread literature survey of these herb revealed that Alpinia sp. is very important medicinal plant with more diverse pharmacological spectrum. The evaluation needs to be carried out on these in order to their uses and formulation of the plants and their other parts in their practical clinical applications, which can be used for the welfare of the mankind. It has been the topic of abundant recent research project because of its in depth use in practice of medicine, however a lot of analysis is required on the extent of it's a lot of potential threat to native flora. So, for welfare of the grouping a lot of analysis can needed for the explore of its therapeutic properties.

\section{Acknowledgements}

Mrs. Vimala Bind contributing in the preparation of manuscript.

\section{Conflict of interest}

The author declares that there is no conflict of interests regarding the publication of this paper.

\section{References}

1. Ibrahim H, Alpinia Zerumbet, Burtt R Smith. Plant Resources of South-East Asia (PROSEA), No. 12(2): Medicinal and poisonous plants. 2001;2:61

2. Acevedo Rodríguez P, Strong MT. Monocots and Gymnosperms of Puerto Rico and the Virgin Islands. Contributions from the United States National Herbarium. 2005;52:415.

3. Oviedo Prieto R, Herrera Oliver P, Caluff MG. National list of invasive and potentially invasive plants in the Republic of Cuba - 2011. (Lista nacional de especies de plantas invasoras y potencialmente invasoras en la República de Cuba-2011). Bissea: Boletín sobre Conservación de Plantas del Jardín Botánico Nacional de Cuba. 2012;6(1):22-96.

4. Macdonald IAW, Reaser JK, Bright C. Invasive alien species in Southern Africa: national reports and directory of resources [ed. by Macdonald IAW, Reaser JK, Bright C, Neville LE, Howard GW, Murphy SJ, Preston G]. Cape Town, South Africa: Global Invasive Species Programme; 2003. p. 125.

5. Smith JE. Exotic Botany: Consisting of Coloured Figures, and Scientific Descriptions, of Such New, Beautiful, or Rare Plants As Are Worthy of Cultivation in the Gardens of Britain. London, UK: R. Taylor and $\mathrm{Co} ; 1804$.

6. ISSG. Global Invasive Species Database (GISD). Auckland, New Zealand: University of Auckland; 2013.

7. Flora of Taiwan Editorial Committee, Taiwan Plant Names. St. Louis, Missouri and Cambridge, Massachusetts, USA: Missouri Botanical Garden and Harvard University Herbaria; 2014.

8. UNIDO. Herbs, spices and essential oils- Post-harvest operations in developing countries. Vienna, Austria: United Nations Industrial Development Organization (UNIDO) and the Food and Agriculture Organization of the United Nations (FAO); 2005.

9. Chan EWC, Lim YY, Chong KL, et al. Antioxidant properties of tropical and temperate herbal teas. Journal of Food Composition and Analysis. 2010;23(2):185-189.

10. Victório CP. Therapeutic value of the genus Alpinia, Zingiberaceae. Revista Brasileira de Farmacognosia. 2011;21(1):194-201.

11. Abdelnaser A Elzaawely, Tran D Xuan, Tawata S. Essential oils ,kawa pyrones and phrnolic compounds from leaves and rhizomes of Alpinia zerumbet (Pers) B.L. Burtt and R.M. Sm and their Antioxidant activity. food Chem. 2007;103(2):486-494. 
12. De Araujo Pincho FVS. Coelho-de-Souza AN, Morais SM, et al. Antinociceptive effects of the essential oil of Alpinia zerumbet on mice. Phytomedicine. 2005;12(6-7):482-6.

13. Haraguchi H, Kuwata Y, Inada K. Planta Medica. 1996;62(4):308-313.

14. Chukanhom K, Borisuthpeth P, Hatai K, Antifungal Activities of Aroma Components from Alpinia galanga against Water Molds. Biocontrol Science. 2005;10(3):105-109.

15. Yamsakul P, Kongkhaew S, Yano T. The antibacterial and bactericidal activity of Alpinia galanga extracts to referent strain of pathogenic bacteria of pig in vivo. Proceedings of the 47th Kasetsart University Annual Conference, Kasetsart, 17-20 March, 2009, Subject: Veterinary Medicine. 2009;208-215.

16. Sunilson JAJ, Suraj R, Rejitha G, et al. In vitro antimicrobial evaluation of Zingiber officinale. American Journal of Food Technology. 2009;4(5):192-200.

17. Hemabarathy B, Budin SB, Feizal V. Paracetamol hepatotoxicity in rats treated with crude extract of Alpinia galanga. Journal of Biological Sciences. 2009;9(1):57-62.

18. Ye Ying, Li BaoAn. 19S-19-Acetoxychavicol acetate isolated from Alpinia galanga inhibits human immunodeficiency virus type 1 replication by blocking Rev transport. Journal of General Virology. 2006;87(7):2047-2053.

19. Bendjeddou D, Lalaoui K, Satta D. Immunostimulating activity of the hot water-soluble polysaccharide extracts of Anacyclus pyrethrum, Alpinia galanga and Citrullus colocynthis. Journal of Ethnopharmacology. 2003;88(2/3):155-160.
20. Akhtar MS, Khan MA, Malik MT. Hypoglycaemic activity of Alpinia galanga rhizome and its extracts in rabbits. Fitoterapia. 2002;73(7/8):623-628.

21. Shivkanya J, Nitin I, Dinesh S. International Journal of Green Pharmacy. 2009:3(2):144-147.

22. Qureshi S, Shah AH, Ahmed MM. The Pharmacological Activities of Alpinia galangal - A Review Ali Esmail Al-Snafi. International Journal of Pharmacognosy. 1994;32(2):171-177.

23. Dadang, Riyanto S, Ohsawa K. Lethal and antifeedant substance from rhizome of Alpinia galanga Sw. (Zingiberaceae). Journal of Pesticide Science. 1998;23(3):304-307.

24. Taira N, Nguyen BC, Tawata S. Hair Growth Promoting and Anticancer Effects of p21-activated kinase 1 (PAK1) Inhibitors Isolated from Different Parts of Alpiniazerumbet. Molecules. 2017;14;22(1).

25. De Souza TA, Lopes MBP, Ramos AS, et al. Alpinia Essential Oils and Their Major Components against Rhodnius nasutus, a Vector of Chagas Disease. Scientific WorldJournal. ;2018:2393858.

26. Santos Júnior L, Oliveira TVC, Cândido JF, et al. Effects of the essential oil of Alpinia zerumbet (Pers.) B.L. Burtt \& R.M. Sm. on healing and tissue repair after partial Achilles tenotomy in rats. Acta Cir Bras. 2017;32(6):449-458. 